\title{
Ecological aspects of Langsdorffia hypogaea (Balanophoraceae) parasitism in the Pantanal wetlands
}

\author{
Carlos Rodrigo Lehn" ${ }^{1}$, Suzana Maria Salis ${ }^{2 \star}$ and Patrícia Póvoa Mattos ${ }^{3}$
}

Received: July 17, 2015 Accepted: September 15, 2015

\begin{abstract}
Most studies on holoparasitic plants have focused on taxonomic or systematic issues. The objective of this study was to examine the ecological aspects of parasitism of Langsdorffia hypogaea (Balanophoraceae) in the Pantanal wetlands. Individuals of L. hypogaea were dug out by hand and the host trees were identified. Eighty-eight percent of host trees exhibited zoochory dispersal syndrome. Protium heptaphyllum and Cordiera sessilis represented 50\% of the sampled trees. Both species are evergreen and are preferentially shade-tolerant species growing under the canopy of other trees. Fecal sample of collared peccaries (Pecari tajacu) had seeds from both the host tree (Protium sp.) and the parasite L. hypogaea. We therefore propose the hypothesis that $P$. tajacu play a role as a seed disperser and may affect root parasitism.
\end{abstract}

Keywords: host specificity, Pantanal, parasite, root, savanna

Most studies on holoparasitic plants have focused on taxonomic or systematic issues aspects, while only a few have examined the ecology of these species, e.g., Ecroyd (1996) and Holzapfel et al. (2001). Bellot \& Renner (2013), who conducted a study on the pollination and reproductive traits of parasitic angiosperms, reported that most of the families that support parasites are pollinated predominantly by insects and by some vertebrates, and that they are dispersed mainly by birds and mammals. However, we are still far from understanding the ecological and evolutionary interactions among hosts, parasites, their pollinators and dispersers, even of the most extensively studied species, because ecological data have been slow to accumulate. The present study aims to identify the biological characteristics of the savanna tree species parasitized by Langsdorffia hypogaea Mart. in Brazil's Pantanal wetlands, and to discuss the relationship of this holoparasite with its host trees.

Langsdorffia hypogaea (Balanophoraceae) is a pantropical root parasite that uses angiosperm trees as hosts (Hansen 1980). In Brazil, L. hypogaea occurs in forests, savannas and savanna woodlands, and usually flowers during the dry season in central-western savannas of the Pantanal wetland region (Pott \& Pott 1994).

The study was conducted at the Nhumirim Experimental Farm (18 $8^{\circ} 59^{\prime} S$ and $56^{\circ} 38^{\prime} \mathrm{W}$ ), located in the sub-region of Nhecolândia in the Pantanal wetlands of the state of Mato Grosso do Sul, Brazil. The regional vegetation comprises $59.6 \%$ of natural pasture, $2.1 \%$ of savannas or "cerrado" (tortuous tree canopy, with underlying shrubs and groundlevel vegetation), 28.9\% of "cerradão" (upper layer of trees of usual "cerrado" species, up to about $13 \mathrm{~m}$ tall and producing a broken canopy, with sparser ground-level vegetation, according to Ratter et al. 1973), and 9.4\% of permanent or temporary ponds (Embrapa 1997). The climate is markedly seasonal (tropical/megathermal), with rainfall prevailing between October and April, with an annual average of $1180.8 \mathrm{~mm}$ (Soriano \& Alves 2005). The annual average maximum temperature varies from $28^{\circ} \mathrm{C}$ to $30^{\circ} \mathrm{C}$ and the absolute maximum temperature may reach $35^{\circ} \mathrm{C}$ in winter and $43^{\circ} \mathrm{C}$ in summer (Soriano \& Alves 2005).

The sampling procedure was carried out from April to June 2007 in areas of "cerrado" and "cerradão". The holoparasite was sampled in these vegetation types on a natural

\footnotetext{
${ }^{1}$ Instituto Federal de Educação, Ciência e Tecnologia Farroupilha, Campus Panambi, Erechim, 860, 98280-000, Panambi, RS, Brazil

${ }^{2}$ Embrapa Pantanal, P.O. Box 109, 79320-900, Corumbá, MS, Brazil

${ }^{3}$ Embrapa Florestas, P.O. Box 319, 83411-000, Colombo, PR, Brazil

*Corresponding author: suzana.salis@embrapa.br
} 
reserve without cattle grazing, and involved searching for inflorescences of the holoparasite by walking along three $250 \mathrm{~m}$ long contour lines (D500, D1500 and F500). These lines are part of a $5 \times 5 \mathrm{~km}$ sampling grid, containing 30 lines spaced at $1 \mathrm{~km}$ intervals, according to Magnusson et al. (2005) (Fig. 1).

The inflorescences of Langsdorffia hypogaea were dug out carefully by hand to reach the root of the host tree. Then, the distance between the parasitized roots and the trunk of host trees was measured. The diameter and depth of the parasitized root were also recorded. The rhizome of L. hypogaea presents several ramifications, making it difficult to quantify the number of parasites per individual host (Fig. 2A).

The host trees were classified according to their leaf phenology (deciduous, semideciduous or evergreen), shadetolerance (heliophyte or sciophyte), dispersal syndromes (anemochory, zoochory or autochory), and period of fruiting, based on information available in the literature (Lorenzi 1992; 1998; Pott \& Pott 1994, Jardim \& Batalha 2009) and on field observations.

Twenty-four Langsdorffia hypogaea host trees were found along the three sampled contour lines, in 12 host species (Tab. 1). Vouchers of L. hypogaea from previous collec- tions at the study site are deposited at the CPAP herbarium (A. Pott 1922, 18/VI/2985; A. Pott 2931, 10/VI/1987; A. Pott 8034, 18/V/1998; V.J. Pott 1407, 03/VII/1990).

The parasitized roots were located at an average depth of $16.4 \pm 3.9 \mathrm{~cm}$, ranging from $6 \mathrm{~cm}$ (in Aspidosperma tomentosum Mart.) to $24 \mathrm{~cm}$ (in Cordiera sessilis Kuntze). On average, the inflorescences were observed about $2.4 \mathrm{~m}$ away from the host trunk. In general, parasitized roots presented small diameters, measuring on average $1.60 \pm 1.40 \mathrm{~cm}$, ranging between 0.3 and $5.1 \mathrm{~cm}$. In two cases, individuals of L. hypogaea were found attached directly to the main root, in the crown area, parasitizing Byrsonima coccolobifolia Kunth and Simarouba versicolor A.St.-Hil. (Fig. 2B).

The point where the holoparasite attached to the host was the most developed portion of the vegetative body of the sampled L. hypogaea, with a diameter ranging from 2.2 to $3 \mathrm{~cm}$. Hsiao et al. (1994) also observed an increase in this diameter in L. hypogaea occurring by sparse and diffuse divisions in the matrix parenchyma of the pith and inner layers of the cortex and, by a more rapid rate of division, in the parenchyma cells. According to these authors, one hypothesis for tuber growth is that the host tissues of the composite bundles are actually "roots," which means

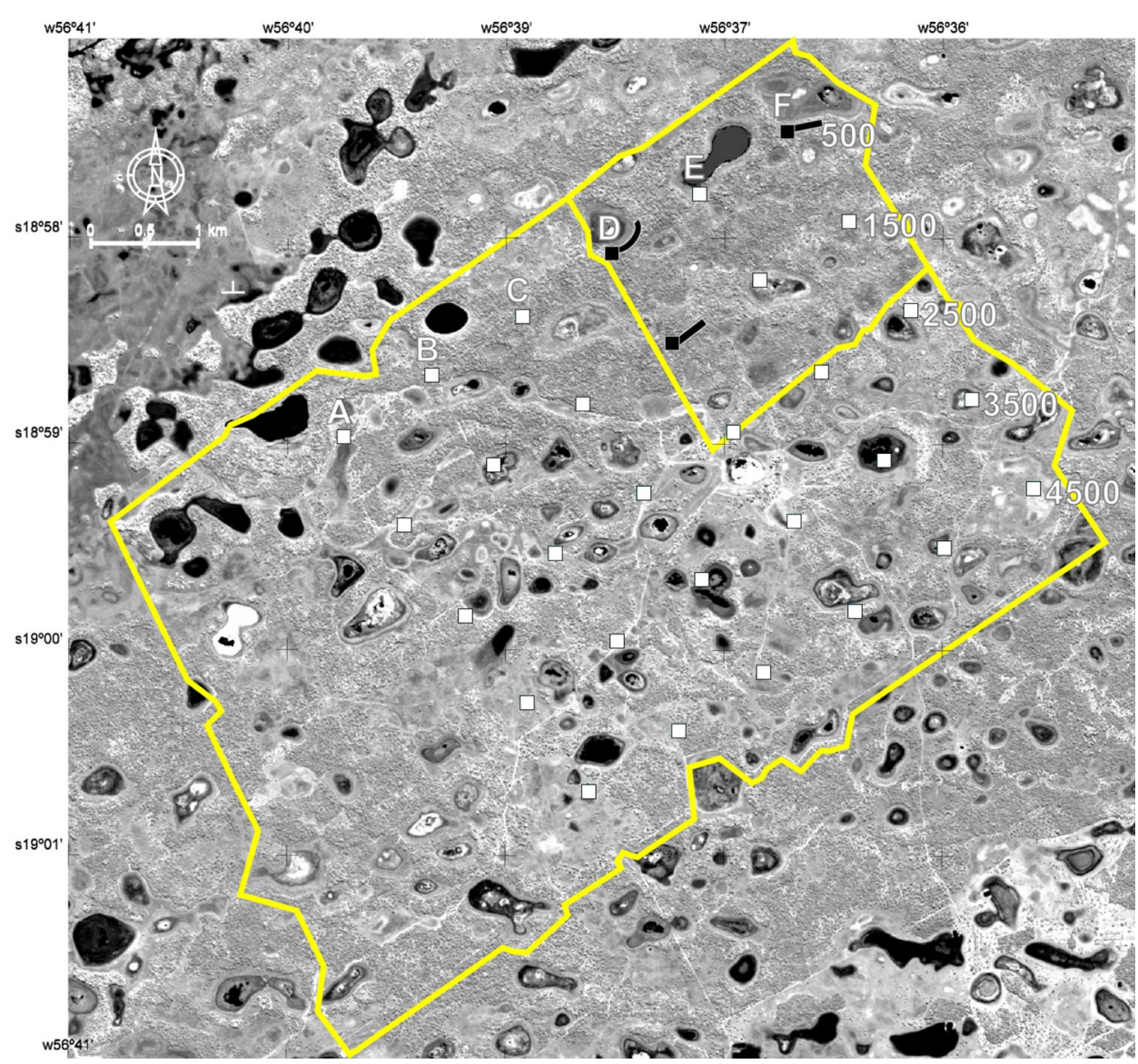

Figure 1. Satellite image of Nhumirim Experimental Farm (inside the yellow border), showing details of sampling grid (in white) and the reserve area (small area demarcated with a yellow line). The holoparasite sampling are identified by black line and squares. Please see the PDF version for color reference. 
Table 1. Tree species parasitized by Langsdorffia hypogaea Mart. (Balanophoraceae) in "cerrado" and "cerradão" on Nhumirim farm in Brazil's Pantanal wetlands.

\begin{tabular}{|c|c|c|c|}
\hline Family and species & Biological characteristics ${ }^{*}$ & $\begin{array}{l}\text { Fructification of zoochorous } \\
\text { tree species* }\end{array}$ & $\begin{array}{c}\text { Number of parasitized } \\
\text { trees }\end{array}$ \\
\hline \multicolumn{4}{|l|}{ Apocynaceae } \\
\hline Aspidosperma tomentosum Mart. & semideciduous $^{2}$, heliophyte ${ }^{2}$, anemochorous ${ }^{4}$ & - & 1 \\
\hline Hancornia speciosa Gomes & semideciduous $^{1}$, heliophyte ${ }^{1}$, zoochorous ${ }^{5}$ & October to April ${ }^{3}$ & 1 \\
\hline \multicolumn{4}{|l|}{ Bignoniaceae } \\
\hline Handroanthus ochraceus (Cham.) Mattos & deciduous $^{1}$, heliophyte ${ }^{1}$, anemochorous ${ }^{4}$ & - & 1 \\
\hline \multicolumn{4}{|l|}{ Burseraceae } \\
\hline Protium heptaphyllum Marchand & evergreen $^{3}$, sciophyte, zoochorous & October to January ${ }^{3}$ & 7 \\
\hline \multicolumn{4}{|l|}{ Cactaceae } \\
\hline Cereus hildmannianus K. Schum. & heliophyte, zoochorous & - & 1 \\
\hline \multicolumn{4}{|l|}{ Dilleniaceae } \\
\hline Curatella americana $\mathrm{L}$. & evergreen, heliophyte ${ }^{1}$, zoochorous $^{3}$ & October to November ${ }^{3}$ & 2 \\
\hline \multicolumn{4}{|l|}{ Fabaceae } \\
\hline Bowdichia virgilioides Kunth & deciduous $^{1}$, heliophyte ${ }^{1}$, anemochorous ${ }^{4}$ & - & 1 \\
\hline \multicolumn{4}{|l|}{ Malpighiaceae } \\
\hline Byrsonima coccolobifolia Kunth & deciduous $^{2}$, heliophyte ${ }^{2}$, zoochorous ${ }^{4}$ & October to March (April) ${ }^{3}$ & 1 \\
\hline \multicolumn{4}{|l|}{ Melastomataceae } \\
\hline Mouriri elliptica Mart. & evergreen, heliophyte, zoochorous ${ }^{4}$ & $\begin{array}{l}\text { December to March, immature } \\
\text { fruits all year long }\end{array}$ & 2 \\
\hline \multicolumn{4}{|l|}{ Myrtaceae } \\
\hline Psidium guineense Sw. & deciduous, heliophyte, zoochorous & $\begin{array}{l}\text { December to March, immature } \\
\text { fruits all year long }\end{array}$ & 1 \\
\hline \multicolumn{4}{|l|}{ Rubiaceae } \\
\hline Cordiera sessilis Kuntze & evergreen $^{3}$, sciophyte to heliophyte ${ }^{2}$, zoochorous & December to February ${ }^{3}$ & 5 \\
\hline \multicolumn{4}{|l|}{ Simaroubaceae } \\
\hline Simarouba versicolor A. St.-Hil.\# & semideciduous ${ }^{2}$, heliophyte ${ }^{2}$, zoochorous & November to December ${ }^{3}$ & 1 \\
\hline Total & & & 24 \\
\hline
\end{tabular}

* Biological characteristics were found in Lorenzi $(1992)^{1}$, Lorenzi $(1998)^{2}$, Pott \& Pott (1994) $)^{3}$, and Jardim \& Batalha (2009)4.

\# Tree sampled outside of the contour lines in the Nhumirim Farm natural reserve.

that they are basically modified host lateral roots growing intrusively through the parasite tissues of the tuber.

The lack of host specialization in Balanophoraceae was noted by Nickrent (2002), who suggested that this family generally occurs in tropical regions because forests have high potential host diversity. In this case, a generalist strategy would offer evolutionary advantages. Nevertheless, we identified most common host trees of Langsdorffia hypogaea associated with evergreen species (70\%), although most species of savanna vegetation present a different phenological strategy ( $44 \%$ of deciduous species and $16 \%$ semideciduous, Pirani et al. 2009), suggesting a role played by leaf phenology.

Half of the sampled roots parasitized were represented by two evergreen species: Protium heptaphyllum Marchand (seven host trees) and Cordiera sessilis (five host trees), which among the most frequent species along the sampled contour lines (DRM Neves unpubl. res.). However, the holoparasite was not observed in other frequent species such as Astronium fraxinifolium Schott, Magonia pubescens A.St.Hil. and Tabebuia aurea (Silva Manso) Benth. \& Hook.f. ex S.Moore (DRM Neves unpubl. res.). Upon comparing the dispersal syndrome of parasitized and non-parasitized (or less parasitized) tree species, we found that most parasitized species are zoochorous (88\%) while non-parasitized species are anemochorous. The high parasitism of $P$. heptaphyllum and $C$. sessilis could be related to the feeding behavior of their seed dispersers. Desbiez et al. (2009) examined the diet of collared peccaries - Pecari tajacu (Linnaeus 1758) in the Pantanal and observed the presence of Langsdorffia hypogaea in $21 \%$ of the fecal samples. In an earlier study, Desbiez (2007) observed the presence of fruits of Protium sp. in $12.5 \%$ of the fecal samples. Simmen et al. (2003) observed lemurs in Madagascar (Lemur catta and Eulemur fulvus) eating mature fruits and seeds of another parasitic 

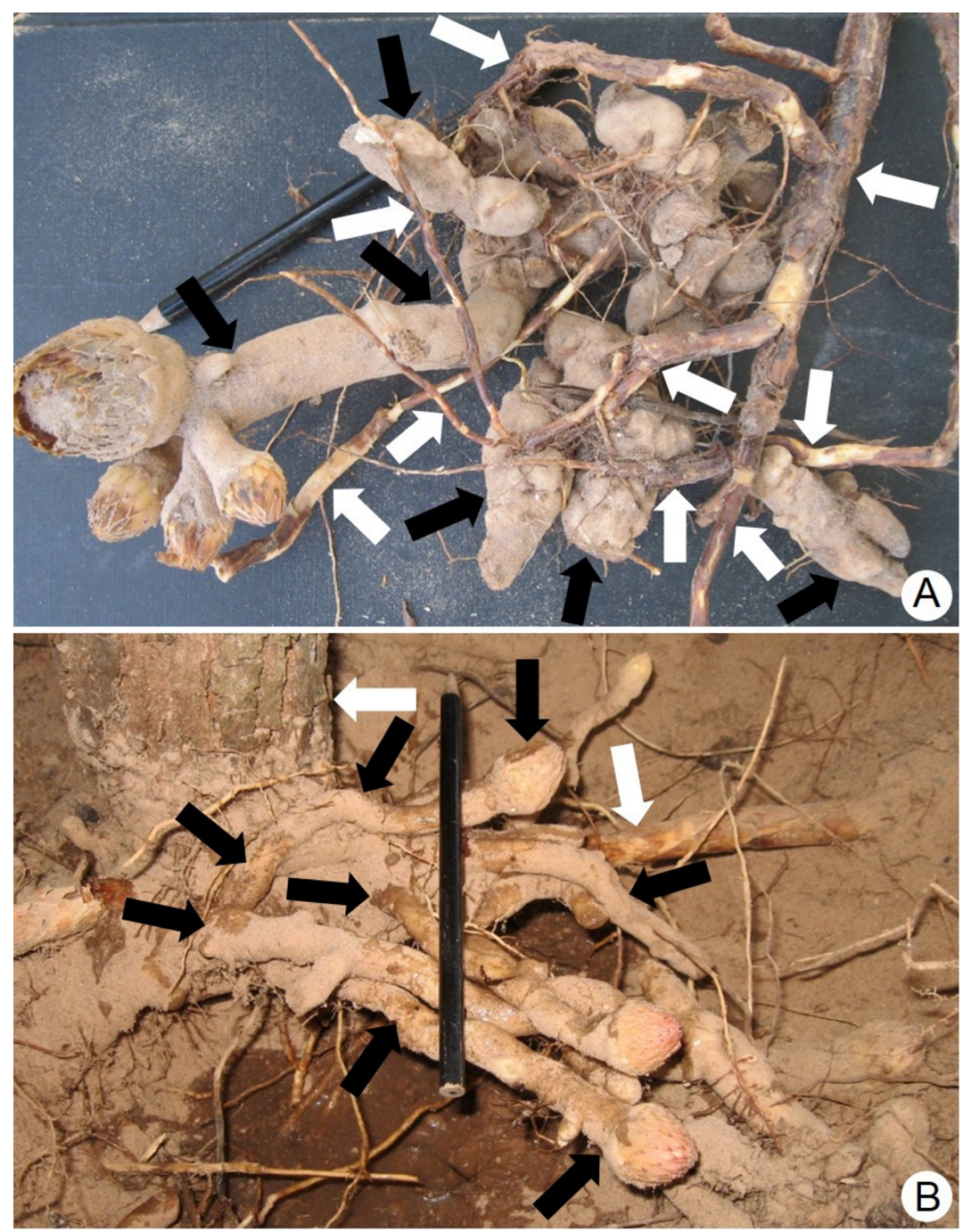

Figure 2. Langsdorffia hypogaea Mart. parasitizing Simarouba versicolor. A. St.-Hil., in the fine roots (A) and the crown area of the main root (B). The black arrow identifies the holoparasite and the white arrow, the host tree.

plant (Hydnora esculenta Jum. \& H. Perrier). We therefore, propose the hypothesis that the collared peccary could be acting as disperser of L. hypogaea, favoring its establishment on available zoochorous host trees because they presumably eat the fruits of both, host and holoparasite. In the study area, L. hypogaea flowers and fruits during the dry season, from April to August, and most of the zoochory host species identified in this study produce fruits at the beginning of the rainy season, before the flowering and fruiting of L. hypogaea. Collared peccaries may eat fruits of L. hypogaea beneath the crown of some potential host trees, and therefore, may disperse seeds from the holoparasite near other fruit trees.

We propose that the disperser syndrome and shady conditions facilitate parasitism by L. hypogaea. However, further investigations involving ecology and biology of both plant and possible dispersers are required to confirm this hypothesis.

\section{Acknowledgements}

We are indebted to Dr. Avi Holzapfel, who provided important suggestions for the first version of the manuscript, to Dr. Ivan Bergier and to Dr. Arnaud Desbiez for their helpful suggestions for this manuscript, and to Luis Alberto Pellegrin from Embrapa Pantanal, for his assistance in mapping the sampling area, and to Dr. Danilo Rafael Mesquita Neves, who kindly provided unpublished information. We also thank Fundação Pantanal Com Ciência for the scholarship.

\section{References}

Bellot S, Renner SS. 2013. Pollination and mating systems of Apodanthaceae and the distribution of reproductive traits in parasitic angiosperms. American Journal of Botany 100: 1083-1094.

Desbiez ALJ. 2007. Wildlife Conservation in the Pantanal: habitat alteration, invasive species and bushmeat hunting. $\mathrm{PhD}$ Thesis, University of Kent Canterbury, United Kingdom. 
Desbiez ALJ, Santos SA, Keuroghlian A, Bodmer RE. 2009. Niche partitioning among white-lipped peccaries (Tayassu pecari), collared peccaries (Pecari tajacu), and feral pigs (Sus scrofa). Journal of Mammalogy 90: 119-128.

Ecroyd CE. 1996. The ecology of Dactylanthus taylorii and threats to its survival. New Zealand Journal of Ecology 20: 81-100.

Embrapa. 1997. Centro de Pesquisa Agropecuária do Pantanal. Plano de utilização da fazenda Nhumirim. Embrapa-CPAP Documentos 21: 1-72.

Hansen B. 1980. Balanophoraceae. Flora Neotropica 23: 1-80.

Holzapfel S, Faville MZ, Gemmill CEC. 2002. Genetic variation of the endangered holoparasite Dactylanthus taylorii (Balanophoraceae) in New Zealand. Journal of Biogeography 29: 663-676.

Hsiao SC, Mauseth JD, Gomes LD. 1994. Growth and anatomy of the vegetative body of the parasitic Angiosperm Langsdorffia hypogaea (Balanophoraceae). Bulletin of the Torrey Botanical Club 121:24-39.

Jardim AVF, Batalha MA. 2009. Dispersal syndromes related to edge distance in cerrado sensu stricto fragments of Central-Western Brazil. Brazilian Archives of Biology and Technology 52: 1167-1177.

Lorenzi H. 1992. Árvores brasileiras: manual de identificação e cultivo de plantas arbóreas nativas do Brasil. Nova Odessa, Editora Plantarum.

Lorenzi H. 1998. Árvores brasileiras: manual de identificação e cultivo de plantas arbóreas nativas do Brasil. 2nd. edn. Vol. 2. Nova Odessa, Editora Plantarum.
Magnusson WE, Lima AP, Luizão R, et al. 2005. RAPELD: a modification of the Gentry method for biodiversity surveys in long-term ecological research sites. Biota Neotropica 5: 1-6.

Nickrent DL. 2002. Plantas parásitas en el mundo. In: López-Sáez JA, Catalán P, Sáez L. (eds.) Plantas parásitas de la Península Ibérica e Islas Baleares. Madrid, Mundi-Prensa Libros. p. 7-27.

Pirani FR, Sanchez M, Pedroni F. 2009. Fenologia de uma comunidade arbórea em cerrado sentido restrito, Barra do Garças, MT, Brasil. Acta Botanica Brasilica 23: 1096-1110.

Pott A, Pott VJ. 1994. Plantas do Pantanal. Brasília, Embrapa SPI.

Ratter JA, Richards PW, Argent G, Gifford DR. 1973. Observations on the vegetation of northeastern Mato Grosso, I. The woody vegetation types of the Xavantina-Cachimbo Expedition area. Philosophical Transactions of the Royal Society of London 226: 449-492.

Simmen B, Hladik A, Ramasiarisoa P. 2003. Food intake and dietary overlap in native Lemur catta and Propithecus verreauxi and introduced Eulemurfulvus at Berenty, Southern Madagascar. International Journal of Primatology 24: 949-968.

Soriano BMA, Alves MJM. 2005. Boletim agrometeorológico ano 2002 para a sub-região da Nhecolândia, Pantanal, Mato Grosso do Sul, Brasil. Embrapa Pantanal Documentos 76: 1-21. 